\title{
The Transformations of the Concept of Fate in Literature
}

\author{
By MOGENS BRØNDSTED
}

The word 'literature' in the title should not be taken only in its strict sense of written literature; we are concerned here with a wider field, including the pre-literaty, oral forms of literature, which are not only fictional, like the folk tale but which also, like myth and legend, represent reality in symbolical form. The idea of fate in such literary forms may seem to be on the level of other great ideas in the history of literature, such as love, nature or society; nevertheless, it holds a special position, firstly because it is probably the most comprehensive and fundamental of these Urprobleme (to use the term of Rudolf Unger, who has considered "Literaturgeschichte als Problemgeschichte"), ${ }^{1}$ and secondly because in a rather unique manner it is woven into the structure of literature and colours the traditional genres of which literature is continuously built up.

In the course of time the literary idea of fate has been subject to a series of transformations which may also be of some interest from the point of view of comparative religion. We shall sketch them in rough outline. The primary point of departure is man's dualistic experience of coming up against an exterior power stronger than himself, which thwarts his actions and intentions. This is supposedly the basic element in all primitive religion: the observation of an external power which decisively controls human life. The first phase, then, is religious, whether this power is conceived to be a plurality of spirits or deities or-most primitive of all, according to a recent trend in comparative religion-as a single 'high god'. The insecurity of the ancient tribal society can be seen in its tendency to discover an arbitrary spiritual will behind all events. But with the growing insight of urban civilization into

\footnotetext{
1 Aufsätze zur Prinzipienlehre der Literaturgeschichte, Berlin, I929 p. I55.
} 
the regularity of nature the idea of a general law arises, which can best be seen in the regular movements of the stars; it is along such lines that the idea of a fixed destiny, perhaps even superior to the gods may have developed. Such an idea already presupposes a certain amount of reflection. When urban society is differentiated to include also a priestly class which dogmatizes the concepts, the result is the theological phase. In those religions where the fixed course of nature plays a predominant part, the task is above all to determine the line of demarcation between this and the gods freedom of action; this is a major point in the Babylonian cosmology, but Indian rita and Greek heimarmene also presuppose, each in its way, an unalterable universal order, more or less moral in its basic character, with or without the cooperation of the gods. In the supranaturalistic monotheistic religions the task is to determine the relation to human freedom of action; here everything is subjected to Yahweh's despotic will or Allah's kismet, and man should use his allotted ethical freedom to carry out this will. Further speculation can boldly free itself from the anthropomorphic idea of god, reaching thus the philosophical phase. The concept of god is merged into an all-comprehensive idea (nature, pantheism), which is superior to man but at the same time contains him; the old dualism, that is to say, is abolished. The feeling of being part of a great universal whole may be combined with the intellectual need to find one all-pervading principle of existence; the different shades of the deterministic ideology are extended to the human psyche and form the transition to the last phase, the psychological. Destiny is now found in man's own breast. The earliest expression of this idea is probably Heraclitus' aphorism that a man's ethos (character) is his daimon. The consistent application of this implies that the development from a transcendent to an immanent idea of fate (i.e., as something inherent in man) has been completed. But the transcendental perspective is not entirely given up unless one is prepared to abandon the whole concept of destiny. In literature, as elsewhere, it is true that previous stages live on as currents under and beside the philosophical and scientific achievements of the time. In his attitude toward the great problems of life, homo sapiens, and especially the subspecies poeta, is rarely a strictly logical being. On the contrary, it must be said that in the mirror of literature fate is conceived of in a series of dialectical categories, i.e. contradictions that can be resolved upon reflection but which for the $12-654218$ Ringgren 
emotional experience remain as poles between which the concept vacillates. These categories refer to either the character of the concept or to its extent.

A. Categories of character.

I. Personal-impersonal (blind). Is there a personified power or a mystical universal force?

2. Moral quality: is it good or evil or indifferent? Is it conceived of as righteous or unrighteous? In other words, is a causal relationship between the volitional act and external fate discovered or found lacking? (cf. the Greek ideas of hybris and nemesis).

3. Transcendence-immanence (see above). Is it located outside of and above man or in man-in the latter case man's character is the determinant. This category comes to the fore especially in the case of the great fatal passions which are felt as alien to the personality and can be ascribed to 'demoniac' influence.

\section{B. Categories of extent.}

I. Individual-universal. Originally the horizon was limited to the tribe itself; for neighbouring tribes other conditions may prevail. Later the tension between individual and collective destiny is added, or the concept receives an aristocratic definition (e.g. nemesis as the consequence of the social level or of the very nature of heroic personality-cf. the poetic theory of 'the tragic height of fall'). A literary work will preferably make the interpretation applicable to the main character, who is the aesthetic centre but who may possess a symbolical value as illustrating a universal condition.

2. Final-causal. Transcendence was originally final (aiming at specific goals, although not necessarily with a conscious intention). Within the given framework, or outside the given limits, human will is free. On the other hand, immanence is causal, i.e. excludes freedom of will.

3. Accidental-necessary. Chance is unforeseeable and capricious (though it is not the result of personal caprice but unintentional and blind); it is often peripheral and minor-but little strokes often fell great oaks. Through such effects it acquires 'fatal' character, since the experience of fate is always connected with central and decisive events. The accidence of fate takes its most extreme form in narratives like the Batak myth of the soul's choice of a leaf 
from the tree of fate in preexistence ${ }^{1}$, or in the Serbian tale of the distribution of the gifts of destiny according to dates of birth. ${ }^{2}$ But just as chance, in philosophical analysis, may fall into various categories, so also, in more immediate experience, it may be considered an aspect of a higher system of necessity. This can be conceived of as equally blind and abstract, indeed as hypostatized inevitability (while the accidental might be avoidable); or it may be understood teleologically, as a conscious super-will, as distinct from divine providence, is inaccessible to prayer or moral efforts. In any case the final result is the same: the fact of predestination.

A condensed account like this sounds speculative, while literature demands concreteness and vividness. Let me quote some typical examples to illustrate this great complex of ideas.

First, predestination can be visualized by the creative imagination through auguries. Poetic augury is something quite different from the auguries of superstition, which can be counteracted or nullified by magic. Literary auguries have the aesthetic effect of concentrating the expectation on a point in the future and thereby increasing the suspense, tightening the structure so to speak. Through the augury the direction of destiny, and thereby of the action, is given or hinted at in advance. In view of this the human will may either surrender in resignation-this is the fatalistic or quietistic attitude; or it may--which is more dramatic and artistically attractive-try to offer resistance. A well known travelling motif from heroic legends is the story of a father and a son who, without knowing one another, engage in battle with the result that one kills the other (cf. the Persian Rustam, the Teutonic Hildebrand, etc.). It is this kind of catastrophic chance that actualizes the problem of fate. To underline the inevitability an augury is added: it is predicted that Oedipus will kill his father (and marry his mother). His father Laios tries to evade the threat by not begetting children and later, after he has forgotten himself in intoxication, by exposing the son and piercing his feet (whence the name Oidi-pous), but the boy is found by shepherds and grows up. These are two examples of an element of action

1 According to this East Indian idea everything is determined before birth. Cf. G. Warneck in Allgemeine Missionszeitschrift 1904 p. 4.

2 See reference in J. Bolte-J. Polívka, Anmerkungen zu den Kinder-und Hausmärchen der Brilder Grimm I, Leipzig 1913 p. 292. 
that is typical of fate literature and may be called 'futile evasion'. Of these the latter works ironically to further the prediction. Oedipus now does not know his real parents; when he himself learns about the prophecy, he flees from his supposed parents, and on his. way he meets his unknown father and the catastrophe happens. But because the legend is bound up with a local hero, the great solver of riddles whose memory was cherished at Colonus, the apparently meaningless element of predetermination acquires significance through the functional combination of greatness, fall and rehabilitation. This is typical of the structure of the heroic legend. In Nordic literature we often meet with a third kind of attitude, without resignation or resistance: this is the heroic acceptance implying that the hero fulfils his destiny and mocks at the prophecies of evil (like Gunnar in the Edda). This attitude is predominant in the heroic poems, where it is a question of being prepared for one's destiny.

All this differs from another ancient genre, the tale, a fireside and daydreamer genre, in which the anonymous hero is often carried to glory by his lucky star or gratuitously endowed with gifts in the cradle by the fairies (fata, fée); after adversity and affliction a reward awaits him at the end. The most wide-spread 'fate-tale'-called in Scandinavia "Rige Per Møller (kræmmer)"-is akin to the Oedipus legend. The rich man hears a prophecy that a certain poor boy will inherit his riches; he has him exposed but he is saved by a shepherd (the first futile evasion). Then he sends the young man with a letter asking the receiver to kill its deliverer-but his daughter or somebody else changes the wording to provide for the daughter's marriage with the deliverer (second futile evasion). In some variants ${ }^{1}$ the rich man makes additional attempts to kill the unwanted son-in-law, but only to his own destruction. The prophecy is here favourable to the main character, and the one who fights the prophecy has become the villain of the action.

A further difference is found in the legend, where moral Providence rules, to the benefit of religious edification. In the Middle Ages the Oedipus motif was applied to Judas, whose disaster brought him to repent and become a disciple of Christ.

'The Oedipus story is best known through Sophocles' treatment of it,

$\therefore{ }^{1} \mathrm{~J}$. Schick, Das Glückskind mit dem Todesbrief, Leipzig 1932; A. Aarne in Folklore Fellows Communications XXIII, r9I6. 
and here we pass from the simple forms of folklore to the use of the same motifs in written litterature. In the tragedy "Oedipus Rex" the prophecy is set in the past and the action of the play consists in its fulfilment-an unwitting fulfilment in which we recognize the ironical structure, but the decisive point is that the main character himself chooses to fulfil the prophecy. The oracle's pronouncement that starts the action is, closely considered, a conditional prophecy: if the plague is to be stopped, the murderer of Laios has to be found-in other words, the hero is given a free choice between two necessities both of which will lead to disaster. This dilemma is the tragic situation proper. The choice that involves great responsibility is from the beginning the kernel of this kind of art, for it was the official festival play of the newly established Athenian democracy. We find it already in the oldest play that has come down to us, the "Suppliants" of Aeschylus, in which King Pelasgus is asked for asylum by the fleeing Danaids: on one side there is the respect for Zeus as the protector of hospitality, on the other hand the regard for the security of the state. He has a choice between violating the cult and thrusting his country into war. Pelasgus is the first tragic figure in world literature.

The epic genre, as it has developed since classical antiquity, differs from this. Both Achilles and Ulysses face a disjunctive prophecy: Achilles is foretold either an early death and eternal fame or a long life without fame; Ulysses is told that he is to fell the suitors either through ruse or in open battle. However, we hear nothing of a real choice. With some simplification one might say that the tragic hero chooses his lot without knowing it; while the epic hero knows his lot without choosing it. The decisions that determine the action are taken by the gods: by the quarrelling lower gods, by the supreme god, or, above even him, by Fate. This tradition in classical literature goes back to Homer's divine apparatus formed out of the multitude of deities and demons of popular belief and arranged by a rationalistic artist who was only bound by one thing: the fixed action of the narrative. This constitutes the determination proper. It may be objected that tragedy, too, is built on stories that are fixed and known in advance, but among other differences, there is a different time dimension. In drama we see, in the sacred 'now' of the festival, the action take shape through human decisions; it is created before our eyes, just as the ancient ritual myths were re-created every year. 
In the enormously extended epic, revolving time itself becomes a determinant of Fate; it brings hither what must happen in the fulness of time in spite of all digressions and embellishments born out of the rhapsodist's imagination. Epic literature does not so much want to show the events as to explain them, to justify the given actions as inspired by gods and demons, to discuss causes and motives. It is an extended oral art, while drama is a concentrated visual art. - A special Nordic form of epic is the Icelandic family saga, which tries to explain historical events psychologically, through the greater or lesser 'luck' ( $g x f a / g i p t a$ ) of the characters; here there occurs a corresponding psychological type of presage, namely the presentiment (hugr) of the wise (most clearly in the Nial saga). Destiny is here on the verge of immanence but retains a mysterious element.

Finally a few words should be said about comedy, which is farthest removed from the sacral origin but in which we can trace two determining elements. ${ }^{1}$ Both point back to the ancient komoi, the pageants in Attica after the wine harvest, in which people walked about roaring songs (kom-oidia), which contained obscenities and ridiculed those standing or living around. The disrespectful lust for mocking at people is seen in the comic action as a teasing of Fate, which works not least of all through surprising chances and accidents (while chance was entirely banished from tragedy). Consequently we find almost no auguries in comedy. Obscenity, an offshoot of the fertility cult, culminated in the burlesque sacred marriage (hieros gamos) -and the fact that the comic action should and must end in the union of the lovers sounds like an echo of this. Dionysus wields his protecting power over them.

Thus the ancient literary genres enter into different combinations with the ideas of fate and each thereby shows its metaphysical aspects. ${ }^{2}$. It is my hope that through this we can reach not only a deeper understanding of the forms of literature but also a more precise definition of fate and the way it is experienced.

I I follow especially F.M. Cornford, The origin of Attic comedy, Cambridge, 1934 (who, however, is not reliable in all details) und G. Murray, Aristophanes Oxford, x933.

2 For further elaboration and documentation reference may be made to my work Digtning og skabne, København 1958 . 